\title{
Germination and growth of ornamental pepper plants due to salinity ${ }^{1}$
}

\author{
Angela Maria dos Santos Pessoa ${ }^{2}$; Elizanilda Ramalho do Rêgo ${ }^{3}$; Marcelo Pereira Cruz ${ }^{4}$; \\ Cristine Agrine Pereira dos Santos ${ }^{5}$; Priscila Duarte Silva ${ }^{6}$; Mailson Monteiro do Rêgo ${ }^{7}$
}

\begin{abstract}
Seeds need favorable environmental conditions to germinate but sometimes these conditions are not available. The goal of this work was to evaluate the influence of different concentrations of $\mathrm{NaCl}$ on in vitro germination and development of Capsicum annuum seedlings. The experiment was conducted at the Laboratório de Biotecnologia Vegetal at Centro de Ciências Agrárias (CCA) of Universidade Federal da Paraíba (UFPB), Areia, $\mathrm{PB}$, Brazil. Ornamental pepper seeds (Capsicum annuum L.) were submitted to five concentrations of $\mathrm{NaCl}$ : $0,25,50,75$ and $100 \mathrm{mM}$. The experimental design was completely randomized, with five treatments and seven replicates, each replicate consisted of one flask with one seed. After 14 days in vitro, the germinated seedlings were characterized for seedling height, hypocotyl width, cotyledon leaf length, cotyledon leaf width, leaf number, radicle length, fresh matter and germination. The data were submitted to analysis of variance by the $\mathrm{F}$ test $(\mathrm{p} \leq$ 0.05). When significant differences were detected, the data were submitted to regression analysis. Percentage of abnormal plantlets was also calculated and submitted to descriptive statistical analysis. The percentage of germination was not affected by the $\mathrm{NaCl}$ concentrations used in this work. However 75 e $100 \mathrm{mM}$ salt concentrations influenced the cotyledonary leaf width, total fresh matter and percentage of abnormal seedlings.
\end{abstract}

Keywords: Capsicum annuum; Salinity; Vigour.

\section{Germinação e crescimento inicial in vitro de pimenteira ornamental em função da salinidade}

\begin{abstract}
Resumo: As sementes necessitam de condições favoráveis para germinar, entretanto, nem sempre existem estas condições. Desta forma, o objetivo desse trabalho foi avaliar a influência de diferentes concentrações de $\mathrm{NaCl}$ na germinação e no crescimento in vitro de plântulas de Capsicum annuum. $\mathrm{O}$ experimento foi conduzido no Laboratório de Biotecnologia Vegetal pertencente ao Centro de Ciências Agrárias (CCA) da Universidade Federal da Paraíba (UFPB), localizado no município de Areia, PB. Foram utilizadas sementes de pimenteira ornamental (C. annuum L.) cultivadas em cinco concentrações de $\mathrm{NaCl}$ : 0, 25, 50, 75 e $100 \mathrm{mM}$. O delineamento experimental foi inteiramente casualizado, com cinco tratamentos e sete repetições, cada repetição foi constituída de um tubo contendo uma semente. Após 14 dias as sementes germinadas in vitro foram caracterizadas quanto a: altura da plântula, diâmetro do hipocótilo, comprimento da folha cotiledonar, largura da folha cotiledonar, número de folhas, comprimento da raiz, matéria fresca e germinação. Os dados foram submetidos à análise de variância pelo teste $\mathrm{F}(\mathrm{p} \leq 0,05)$, quando detectadas diferenças significativas os dados foram submetidos à análise de regressão. A porcentagem de plantas anormais também foi calculada e submetida à análise por meio de estatística descritiva. A germinação das sementes de pimenteiras não foi afetada pelas doses de $\mathrm{NaCl}$ utilizadas neste trabalho, entretanto as concentrações de 75 e $100 \mathrm{mM}$ de sal afetaram a largura da folha cotiledonar, a massa fresca total e a porcentagem de plantas anormais.
\end{abstract}

Palavras-chave: Capsicum annuum; Estresse salino; Vigor.

\footnotetext{
${ }^{1}$ Submetido em 27/12/2017 e aprovado em 11/03/2018

${ }^{2}$ Doutora em Agronomia; Bolsista PNPD, Universidade Federal da Paraíba (UFPB), Centro de Ciências Agrária, Programa de Pós-Graduação em Agronomia, Areia-PB, CEP: 58397-000; E-mail: angelapessoapb@gmail.com

${ }^{3}$ Doutorado em Genética e Melhoramento; Professora Associada, Universidade Federal da Paraíba (UFPB), Centro de Ciências Agrária, Departamento de Ciências Fundamentais e Sociais, Areia-PB, CEP: 58397-000; E-mail: elizanilda@cca.ufpb.br

${ }^{4}$ Mestre em Agronomia; Doutorando, Universidade Federal da Paraíba (UFPB), Centro de Ciências Agrária, Programa de Pós-Graduação em Agronomia, Areia-PB, CEP: 58397-000; E-mail: marcelo152act@ hotmail.com

${ }^{5}$ Mestre em Agronomia; Doutorando, Universidade Federal da Paraíba (UFPB), Centro de Ciências Agrária, Programa de Pós-Graduação em Agronomia, Areia-PB, CEP: 58397-000; E-mail: cristineagrine.ps@ @otmail.com

${ }^{6}$ Graduanda em Agronomia, Universidade Federal da Paraíba (UFPB), Centro de Ciências Agrária, Areia-PB, CEP: 58397-000; e-mail: silvapriscilad@gmail.com

${ }_{7}^{7}$ Doutor em Genética e Melhoramento; Professor Adjunto III, Universidade Federal da Paraíba (UFPB), Centro de Ciências Agrária, Departamento de Ciências Biológicas, Areia-PB, CEP: 58397-000; E-mail: mailson@cca.ufpb.br
} 


\section{Introdution}

The pepper species of the genus Capsicum are members of the Solanaceae family (De Witt and Bosland, 2009) and are native to the tropical regions of Central and South America. This genus has 5 cultivated species, $C$. апnиum L., $C$. frutescens $\mathrm{L}$., C. chinense $\mathrm{L} .$, C. baccatum $\mathrm{L}$. and C. pubescens L. (Bosland, 1992).

Peppers are appreciated all over the world for possessing pungent fruits and various nutrients, including flavonoids, carotenoids and essential minerals. Pepper plants can be used as functional, medicinal and aromatic plants, as well as ornamental plants in condiment gardens or in internal environments, adding value to the product and increasing the financial return to the producers (Rêgo et al., 2015; Rêgo e Rêgo, 2016, 2018). Its production is also associated with its adaptation to different climatic regions (Qin et al., 2014).

Biotic and abiotic stresses limit plant growth and development. Among the abiotic stresses, water and salinity affect seedling survival and plant growth (Fanti and Perez, 2004).

Excess soil salts, particularly $\mathrm{NaCl}$, cause three main types of plant stress: the osmotic, the ionic and the oxidative. These forms of stress reduce absorption and induce massive loss of water and ions $\left(\mathrm{K}^{+}\right)$in plant cells, resulting in a water and nutritional imbalance. The accumulation of $\mathrm{Na}^{+}$in toxic concentrations and the production of reactive oxygen species reduces the growth and production of important crops, such as cereals and vegetables (Munns and Tester, 2008; Bojórquez-Quintal et al., 2012). Salt tolerance is complex and controlled by several genes that are involved in different physiological and biochemical mechanisms (Zhang and Shi, 2013; Adams et al., 2014).

These stresses also negatively affect seed germination and plant stand and can, in some cases, lead to death (Taiz et al., 2017). The excess $\mathrm{NaCl}$ can also inhibit seed germination due to the reduction of water potential, inducing a lower water absorption capacity (Lima et al., 2005).

These effects depend on the differentiated sensitivity to the salt stress conditions of each plant species (Martins et al., 2011; Matias et al., 2015).
Despite their development in different environments, pepper are sensitive to saline stress, and genotypes that are moderately sensitive, sensitive or highly sensitive to salinity can be found (Maas and Hoffman, 1977; Aktas et al., 2006).

Bojórquez-Quintal et al. (2014) reported that despite the economic importance of pepper, little is known about the mechanisms of tolerance to high salt concentrations.

The percentage of seed germination in saline substrates has been one of the most widespread methods to infer salinity tolerance (Rabbani et al., 2013).

The objective of this study was to evaluate the influence of different concentrations of $\mathrm{NaCl}$ on the germination and in vitro growth of Capsicum annuum seedlings.

\section{Materials and Methods}

The experiment was carried out at the Laboratório de Biotecnologia Vegetal, Centro de Ciências Agrárias (CCA), Universidade Federal da Paraíba (UFPB), Areia, PB. Ornamental pepper seeds (Capsicum annuиm L.) from cultivar Etna were used as plant material.

The seeds were disinfested in a laminar flow chamber in 1:1 (v/v) sodium hypochlorite solution and distilled, deionized and autoclaved water (DDA) for 10 minutes, then washed three times with distilled, deionized and autoclaved water (DDA), for complete removal of residues from the sanitizing solution. They were then inoculated into test tubes $(25$ x $125 \mathrm{~mm})$ containing $10 \mathrm{~mL}$ of MS medium (Murashige and Skoog, 1962), pre-sterilized in an autoclave at $120^{\circ} \mathrm{C}$ for $15 \mathrm{~min}$ and $\mathrm{pH}$ adjusted to $5.7 \pm 0.1$, plus $30 \mathrm{~g} \mathrm{~L}^{-1}$ sucrose, $8 \mathrm{~g} \mathrm{~L}^{-1}$ agar and the following salt concentrations: 0 (control), $25 \mathrm{mM}$ (1.462 $\mathrm{g} \mathrm{L}^{-1}$ of $\left.\mathrm{NaCl}\right), 50 \mathrm{mM}\left(2.925 \mathrm{~g} \mathrm{~L}^{-1}\right.$ of $\mathrm{NaCl}), 75 \mathrm{mM}\left(4.387 \mathrm{~g} \mathrm{~L}^{-1} \mathrm{NaCl}\right)$ and $100 \mathrm{mM}$ (5.850 $\mathrm{g} \mathrm{L}^{-1}$ of $\left.\mathrm{NaCl}\right)$, established according to Lima et al. (2005), Rabbani et al. (2013) and Harter et al. (2014).

The tubes were maintained in a growth room with controlled temperature of $24 \pm 2{ }^{\circ} \mathrm{C}$ with photoperiod of $16 \mathrm{~h}$ under fluorescent light with intensity of $40 \mu \mathrm{mol} \mathrm{m} \mathrm{m}^{-2} \mathrm{~s}^{-1}$. Seeds germinated with radicular protrusion were counted 14 days after the test, according to the Rules for Seed 
Analysis - RAS (Brazil, 2009). The results were expressed as percentage.

Seedlings were measured for the following variables: seedling height $(\mathrm{SH})$, radicle length (RL), hypocotyl diameter (HD), cotyledon leaf length (CLL), Cotyledon leaf width (CLW), number of leaves (NL) and total fresh mass (FM). The normal seedlings that survived were kept in a greenhouse to evaluate saline stress in the other stages of growth.

In addition, the percentage of abnormal plants for each treatment was calculated. Seedlings considered normal and abnormal were recorded by photographs and submitted to descriptive statistics analysis.

The experimental design was completely randomized, with five treatments and seven replicates per treatment (one seed per tube).

Data were submitted to analysis of variance and regression non-adjustment test $(\mathrm{p} \leq 0.05)$.
Regression analysis was performed when the non-adjustment test was non-significant. The analyses were performed using the computer program Genes (Cruz, 2006).

\section{Results and Discussion}

There was a significant effect among treatments for cotyledon leaf width $(\mathrm{p} \leq 0.05)$ and fresh mass $(\mathrm{p} \leq 0.01)$. The other characteristics were not affected by the doses of salts (Table 1). The lack of fit of the linear regression model was significant for all variables, except for the CLW and FM variables (data not shown).

The experimental precision (coefficient of variation) varied between $21.50 \%$ for the cotyledonary leaf width and $101.20 \%$ for the hypocotyl diameter (Table 1). In peppers, CV values vary according to the characteristic, genotype and species under study (Da Silva et al., 2011).

Tabela 1 Summary of variance analysis for seedling characteristics in ornamental pepper (Capsicum annuum L.) submitted to saline stress

\begin{tabular}{|c|c|c|c|c|c|c|c|c|c|}
\hline \multirow{2}{*}{ F.V. } & \multirow{2}{*}{ GL } & \multicolumn{8}{|c|}{ Mean Square } \\
\hline & & $\mathrm{SH}$ & HD & $\mathrm{RL}$ & CLL & CLW & NL & $\overline{\text { FM }}$ & $\overline{\mathrm{GE}}$ \\
\hline Traits & 4 & $0.90^{\mathrm{ns}}$ & $0.02^{\mathrm{ns}}$ & $4 . .06^{\mathrm{ns}}$ & $0.11^{\mathrm{ns}}$ & $0.02 *$ & $3.04^{\mathrm{ns}}$ & $0.01 * *$ & $0.17^{\mathrm{ns}}$ \\
\hline Residue & 30 & 0.46 & 0.02 & 3.16 & 0.06 & 0.01 & 2.40 & 0.02 & 0.09 \\
\hline & & 2.44 & 0.14 & 6.58 & 1.11 & 0.39 & 4.77 & 0.12 & 0.88 \\
\hline & & 27.80 & 101.20 & 27.00 & 22.94 & 21.51 & 32.46 & 35.74 & 34.84 \\
\hline
\end{tabular}

** and * Significant at the $1 \%$ and 5\% error probability level, by the t test, respectively. SH - Seedling height; HD - hypocotyl diameter; RL - radicle length; CLL - Cotyledon leaf length; CLW - Cotyledon Leaf Width; NL - Number of leaves and MF

- Fresh matter; GE - Germination.

The percentage of germination at the doses tested in this study was higher than $70 \%$ (data not shown). These results are within the expected levels to be considered effective germination, since $70 \%$ is the minimum of germination recommended for the commercialization of basic seeds of the genus Capsicum, in accordance with Administrative Rule 457 of December 18, 1986 (Brazil, 1986), and with the Draft Normative Instruction of September 5, 2012 (Brazil, 2012).

Guzmán-Murillo et al. (2013) reported a decrease in germination at the concentration of 50 $\mathrm{mM}$ on the germination of $C$. апnиит. Hassen et al. (2014) reported that the effects of saline stress on the germination of this species were dependent on the cultivar, with the Anaheim cultivar tolerant to the highest $\mathrm{NaCl}$ dose used $12 \mathrm{gL}^{-1}$ whereas other cultivars were susceptible to saline stress. The negative effects of increasing $\mathrm{NaCl}$ doses on the culture medium on germination may be related to the reduction of water absorption and the toxic accumulation of ions in the embryo (Hassen et al., 2014). Zapata et al. (2004) demonstrated that the germination and the total fresh matter of pepper plants were affected in the $150 \mathrm{mM}$ dose. Zhani et al. (2012) reported a decrease in germination in different cultivars of C. frutescens pepper at concentrations ranging from 2 to $8 \mathrm{~g} \mathrm{~L}^{-1}$.

The cotyledon leaf width (Figure 1) and total fresh matter (Figure 2) were inversely proportional to the concentration of salts in the culture medium. 


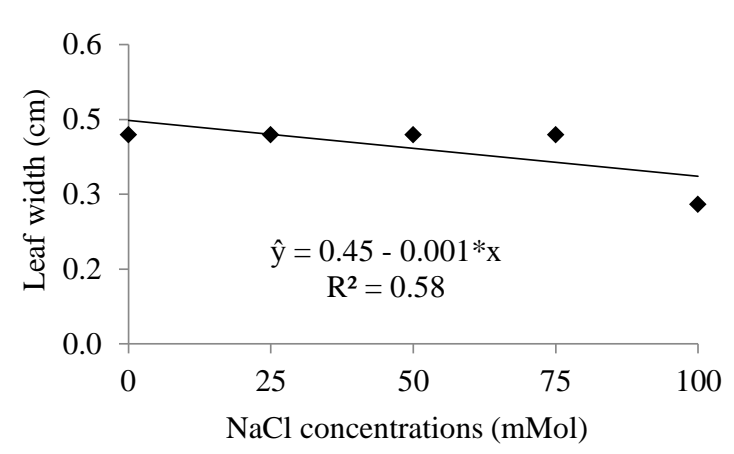

Figure 1 Cotyledon leaf width in Capsicum annuum cultivated in vitro as a function of the $\mathrm{NaCl}$ concentration.

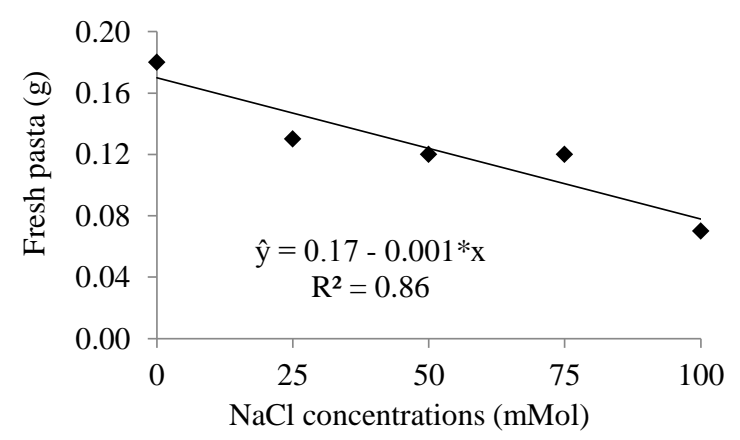

Figure 2 Total fresh mass in Capsicum annuum cultivated in vitro as a function of $\mathrm{NaCl}$ concentration.

Guzmán-Murilloet al., (2013) reported a decrease in the hypocotyl and root measurements in pepper, in the concentration of $50 \mathrm{mM} \mathrm{NaCl}$, but not in $25 \mathrm{mM}$. Similar data were found for the species $C$. frutescens by Zhani et al. (2012). These same authors reported a decrease in the number of leaves and leaf area with the increase in $\mathrm{NaCl}$ concentration.

In relation to fresh matter, Hassen et al. (2014) working with different cultivars of $C$. annuиm found data similar to this work. These authors reported decreases in fresh matter in the doses of $\mathrm{NaCl}$ being tested with Anaheim cultivar showing tolerance to the greater dose used $\left(12 \mathrm{~g} \mathrm{~L}^{-1}\right)$ and the other cultivars being susceptible. Zapata et al. (2004) reported a reduction of $10 \%$ in fresh matter in pepper, in relation to the control plants, in the concentration of $150 \mathrm{mM}$. In this work the reduction in the total fresh matter was $38.88 \%$ in the dose of $100 \mathrm{mM}$. Guzmán-Murilloet al. (2013) also reported a decrease of the total fresh matter in pepper in the concentration of $50 \mathrm{mM}$ of $\mathrm{NaCl}$.

According to Bojórquez-Quintal et al. (2012) high concentrations of salts can cause severe damage to peppers of the genus Capsicum, making them highly sensitive to saline stress. These same authors emphasized that the damage caused to seedlings is more severe and can result in growth retardation and even death. On the other hand, Arrowsmith et al. (2012) reported that peppers may be more tolerant of salt stress than expected for the genus. It is worth noting that the percentage of salt in the medium tested by the latter authors may have been insufficient to cause damage to the seedlings and concluded that further tests at higher concentrations should be done. Bojórquez-Quintal et al. (2014) found differences between Chichen-Itza and Rex varieties belonging to the $\mathrm{C}$. chinense species at different $\mathrm{NaCl}$ concentrations, the latter being more tolerant at the $100 \mathrm{mM}$ dose. However, the $150 \mathrm{mM}$ dose affected both cultivars, causing loss of fresh matter, foliar abscission and root darkening.

In this work, the highest percentage of abnormal seedlings were found at the highest concentrations of $\mathrm{NaCl}$. At zero concentration there was a higher occurrence of normal plants $(80 \%)$ and less of abnormal seedlings (20\%) (Figure 3A). In contrast, in the highest concentration of $\mathrm{NaCl}(100 \mathrm{mM}) 40 \%$ of abnormal plants were detected (Figure 3B, C). Abnormal seedlings with atrophied hypocotyl and roots (Figure 3B) as well as seedlings with normal root and abnormal aerial part were found (Figure 3C). These results confirm the reported by Bojórquez-Quintal et al. (2012) in relation to damage caused to seedlings in response to increased salinity in the environment.

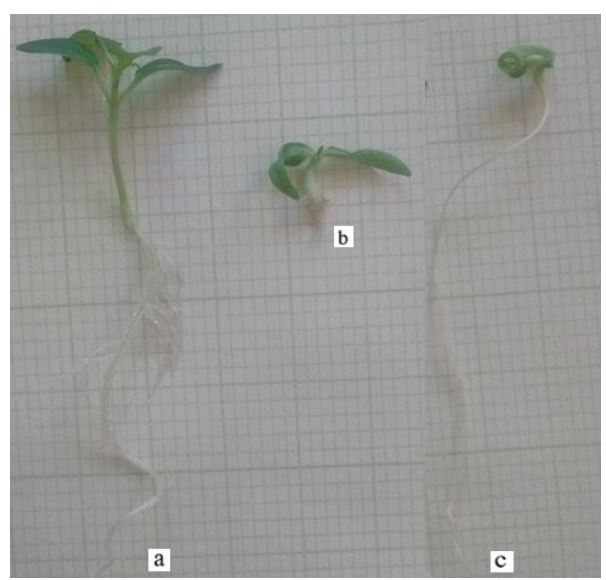

Figure 3 Normal ornamental plantlet (a), abnormal plantlet with atrophied roots and hypocotyl (b) and abnormal plantlet with normal roots and atrophied aerial part (c). 
According to BRASIL (1992), abnormal plants are those that show no potential to continue their growth and give rise to normal plants. While this concept also applies to abnormal plants that grow in ideal conditions, abnormal growth can be caused by high concentrations of salts that reduce the osmotic potential, which can lead to the action of ions on the protoplasm (Mortele et al., 2006).

\section{Conclusion}

The germination of the pepper seeds was not affected by the $\mathrm{NaCl}$ doses used in this work, however the concentrations of 75 and $100 \mathrm{mM}$ of salt affected the cotyledon leaf width, the total fresh mass and the percentage of abnormal plants.

\section{Acknowledgment}

The authors thank the programa de PósGraduação em Agronomia of Universidade Federal da Paraíba. Thanks also to Conselho Nacional de Desenvolvimento Científico e Tecnológico $(\mathrm{CNPq})$ and to Coordenação de Aperfeiçoamento de Pessoa de Nível Superior (CAPES) for their financial assistance (grants).

\section{References}

Adams, E.; Shin, R. Transport, signaling, and homeostasis of potassium and sodium in plants. Journal of integrative plant biology, v.56, n.3, p.231-249, 2014. http://doi.or/10.1111/jipb.12159

Aktas, H., Abak, K.; Cakmak, I. Genotypic variation in the response of pepper to salinity. Scientia Horticulturae, v.110, n.3, p.260-266, 2006. https://doi.org/10.1016/j.scienta.2006.07.017

Arrowsmith, S.; Egan, T. P.; Meekins, J. F.; Powers, D.; Metcalfe, M. Effects of salt stress on capsaicin content, growth, and fluorescence in a Jalapeño cultivar of Capsicum annuum (Solanaceae). Bios, v.83, n.1, p.1-7, 2012. http://www.jstor.org/stable/23267852

Bojórquez-Quintal, E.; Velarde-Buendía, A.; KuGonzález, Á.; Carillo-Pech, M.; OrtegaCamacho, D.; Echevarría-Machado, I.; Martínez-Estévez, M. Mechanisms of salt tolerance in habanero pepper plants (Capsicum chinense Jacq.): proline accumulation, ions dynamics and sodium root-shoot partition and compartmentation. Frontiers in plant science, $\begin{array}{llll}\text { v. } 5, & \text { p. } & 1-14, & \end{array}$ https://doi.org/10.3389/fpls.2014.00605
Bojórquez-Quintal, J. E.; Echevarría-Machado, I.; Medina-Lara,F.; Andmartínez-Estévez, M. Plants challenges in a salinized world: the case of Capsicum. African Journal of Biotechnology. v.11, n.72, p.13614-13626, 2012. https://doi.org/10.5897/AJB12.2145

Bosland, P.W. Chiles: A diverse crop. HortTechnology, v.2, n.1, p.6-10, 1992. http://horttech.ashspublications.org/content/2/1/6.full.pdf $\underline{+\mathrm{html}}$

BRASIL, Ministério da Agricultura e Reforma Agrária. Regras para análise de sementes. SNAD, CLAV, Brasília, 1992. 395p.

BRASIL. Ministério da Agricultura, Pecuária e Abastecimento. Portaria n 111, de 4 de setembro de 2012. Estabelece os padrões de identidade e qualidade para a produção e a comercialização de sementes de espécies olerícolas, condimentares, medicinais e aromáticas, disposto em anexo. Diário Oficial [da] República Federativa do Brasil, 5 set. 2012. Seção 1, p.3-4.

BRASIL. Ministério da Agricultura. Portaria n 457, de 18 de dezembro de 1986. Estabelece para todo o território nacional, procedimentos e padrões de sementes olerícolas, para distribuição, transporte, e comércio de sementes fiscalizadas, e para importação. Diário Oficial [da] República Federativa do Brasil, 23 dez. 1986. Seção 1, p.19653.

BRASIL. Ministério da agricultura. Regras para análise de sementes. Brasília: DNDV/CLAV, 2009.

http://www.agricultura.gov.br/assuntos/insumos394p. agropecuarios/arquivos-publicacoesinsumos/2946 regras analise sementes.pdf

Cruz, C. D. Programa genes (versão Windows): aplicativo computacional em genética e estatística. Viçosa: Editora UFV, 2006.382p.

Da Silva, A. R.; Cecon, P. R.; Rêgo, E. R.; Nascimento, M. Avaliação do coeficiente de variação experimental para caracteres de frutos de pimenteiras. Revista Ceres, v.58, n.2, p.168171, 2011. http://dx.doi.org/10.1590/S0034737X2011000200006

De Witt, D.; Bosland, P.W. The complete chilli pepper book: a gardeners guide to choosing, growing, preserving and cooking. London: Timber Press., 2009. 336p. 
Fanti, S. C.; Peres, S. C. J. G. A. Processo germinativo de sementes de paineira sob estresses hídrico e salino. Pesquisa Agropecuária Brasileira, v.39, n.9, p.903-909, $2004 . \quad$ http://dx.doi.org/10.1590/S0100204X2004000900010

Guzmán-Murillo, M. A.; Ascencio, F.; LarrinagaMayoral, J. A. Germination and ROS detoxification in bell pepper (Capsicum annuит L.) under $\mathrm{NaCl}$ stress and treatment with microalgae extracts. Protoplasma, v. 250, n. 1, 33-42.

2013.

https://link.springer.com/article/10.1007\%2Fs00709-0110369-z.

Harter L. S. H; Harter F. S; Deuner, C.; Meneghello, G.E.; Villela, F. A. Salinidade e desempenho fisiológico de sementes e plântulas de morango. Horticultura Brasileira, v.32, n.1, p.80-85, 2014. http://dx.doi.org/10.1590/S0102$\underline{05362014000100013}$

Hassen, A.; Maher, S.; Cherif, H. Effect of salt stress $(\mathrm{NaCl})$ on germination and early seedling parameters of three pepper cultivars (Capsicum anпиит L.). Journal of Stress Physiology \& Biochemistry, v.10, n.1, p.14-25, 2014. https://cyberleninka.ru/article/v/effect-of-salt-stress-naclon-germination-and-early-seedling-parameters-of-threepepper-cultivars-capsicum-annuum-1

Lima, M. G. S.; Lopes, N. F.; Moraes, D. M.; Abreu, C. M. Qualidade fisiológica de sementes de arroz submetidas a estresse salino. Revista Brasileira de Sementes, v.27, n.1, p.54-61, $2005 . \quad$ http://dx.doi.org/10.1590/S0101$\underline{31222005000100007}$

Maas, E. V.; Hoffman, G. J. Crop salt tolerancecurrent assessment. Journal of the irrigation and drainage division, v.103, n.2, p.115-134, 1977.

https://www.researchgate.net/publication/245816881_Cro p_Salt_Tolerance-Current_Assessment

Martins, C. C.; Pereira, M. R. R.; Marchi, S. R. Germinação de sêmentes de Melaleuca quinquenervia em condições de estresse hídrico e salino. Planta Daninha, v. 29, n. 1, p. 1-6, 2011.

http://doi.org/10.1590/S010083582011000100001

Matias, J. R.; Silva, T. C. F. S.; Oliveira, G. M.; Aragão, C. A.; Dantas, B. F. Germinação de sementes de pepino cv. caipira em condições de estresse hídrico e salino. Revista Sodebras, v.10, n.113, p.33-39, 2015. https://ainfo.cnptia.embrapa.br/digital/bitstream/item/123 495/1/Barbara-3.pdf

Moterle, L. M.; Lopes, P. C.; Braccini, A. L.; Scapim, C. A. Germinação de sementes e crescimento de plântulas de cultivares de milhopipoca submetidas ao estresse hídrico e salino. Revista Brasileira de Sementes, v.28, n.3, p.169-176, 2006. http://dx.doi.org/10.1590/S0101$\underline{31222006000300024}$

Munns, R., Tester, M. Mechanisms of salinity tolerance. Annual Review of Plant Biology, v.59, p.651-681, 2008. https://doi.org/10.1146/annurev.arplant.59.032607.09291 $\underline{1}$

Murashige, T.; Skoog, F. A. A revised medium for rapid growth and bioassays with tobacco tissue culture. Physiologia Plantarum, v.15, n.3, p.473-497, 1962. https://doi.org/10.1111/j.13993054.1962.tb08052.x

Qin, C., Yu, C., Shen, Y., Fang, X., Chen, L., Min, J. Cheng, J.;Zhao, S.; Xu, M.; Luo, Y.;Yang, Y.; Wu, Z.; Mao, L.; Wu, H.; LingHu, C.; Zhou, H.; Lin, H.; González-Moralews, S.; Trejo-Saavedra, D. L.; Tian, H.; Tang, X.; Zhao, M.; Huang, Z.; Zhou, A.; Yao, X.; Cui, J.; Li, W.; Chen, Z.; Feng, Y.; Niu, Y.; Bi, S.; Yang, X.;Li, W.; Cai, H.; Luo, X.; MontesHernández, S.; Leyva-González, M. A.; Xiong, Z.; X.; Bai, L.; Tan, S.; Tang, X.; Lui, D.; Lui, J.; Zhang, S.; Chen, M.; Zhang, L.; Zhang, Y.; Liao, W.; Zhang, Y.; Wang, M.; Lv, Xiaodan, Wen, Bo,. Lui, H.; Luan, H.; Zhang, Y.; Yang, S.; Wang, X.; Xu, J.; Li, X.; Li, S.; Wang, J.; Palloix, A.; Bosland, P. W.; Li, Y.; Krogh, A.; Rivera-Bustamante, R. F.; Herrera-Estrella, L.; Yin, Ye, Y.; Yu, J.; Hu, K.; Zhang, Z. Wholegenome sequencing of cultivated and wild peppers provides insights into Capsicum domestication and specialization. Proceedings of the National Academy of Sciences, v.111, n.14, p.5135-5140, 2014. http://www.pnas.org/content/pnas/111/14/5135.full.pdf.

Rabbani, A. R. C.; Silva-Mann, R.; Ferreira, R. A.; Carvalho, S. V. À.; Nunes, F. B. S.; Brito, A. S. Efeito do estresse salino sobre atributos da germinação de sementes de girassol. Scientia Plena, v.9, n.5, p.1- 6, 2013. https://www.scientiaplena.org.br/sp/article/viewFile/555/ $\underline{775}$

Rêgo, E. R.; Rêgo, M. M. Genetics and breeding of chili pepper Capsicum spp. In: Rêgo, E. R.; Rêgo, M. M.; Finger, F. L. Production and 
breeding of chilli peppers (Capsicum spp.). Springer International Publishing Switzerland, $2016 . \quad$ p.1-129. https://link.springer.com/chapter/10.1007/978-3-319$\underline{06532-8 \_4}$

Rêgo, E. R.; Rêgo, M. M. Ornamental pepper. In: Van Huylenbroeck, J. Ornamental crops. Springer International Publishing Switzerland, 2018 (in press). http://www.springer.com/br/book/9783319906973.

Rêgo, M. M.; Sapucay, M. J. L. C.; Rêgo, E. R.; Araújo, E. R. Analysis of Divergence and Correlation of Quantitative Traits in Ornamental Pepper (Capsicum spp.). Acta Horticulturae, v.1087, p.389-394, 2015. https://www.actahort.org/books/1087/1087_52.htm

Taiz, L.; Zeiger, E.; Moller, I.; Murphy, A. Fisiologia e desenvolvimento vegetal. $6^{a}$.ed. Porto Alegre: Artmed, 2017. 888p.
Zapata, P. J.; Serrano, M., Pretel, M. T., Amorós, A.; Botella, M. Á. Polyamines and ethylene changes during germination of different plant species under salinity. Plant Science, v.167, n.4, p.781-788, 2004. https://doi.org/10.1016/j.plantsci.2004.05.014.

Zhang, J. L.; Shi, H. Physiological and molecular mechanisms of plant salt tolerance. Photosynthesis research, v.115, n.1, p.1-22, 2013. http://doi.org/10.1007/s11120-013-9813-6

Zhani, K.; Elouer, M. A.; Aloui, H.; Hannachi, C. Selection of a salt tolerant Tunisian cultivar of chili pepper (Capsicum frutescens). European Asian Journal of BioSciences, v.6, p.47-59, 2012.

https://www.researchgate.net/publication/232685071_Sel ection_of_a_salt_tolerant_Tunisian_cultivar_of_chili_pep per Capsicum frutescens 